\title{
A FEMINIST REVIEW ROUNDTABLE ON THE (UN)CERTAINTIES OF THE ROUTES OF THE COLLECTIVE AND THE JOURNAL
}

\begin{abstract}
The following text has been generated from three roundtable discussions which took place over a series of months between several members from the editorial Collective. These conversations reflected on significant intellectual turning points in the journal as well as shifts and continuities in the dynamics and politics of the Collective itself. So, in this roundtable we have chosen to celebrate 25 years of existence, by sharing reflections on the productive un/certainties that have been critical to the routes we have taken as well those we may take, both as a journal and as a Collective, with our readers. The place of academia, politics, global feminism as well as our own affective bonds and labour form a part of this ongoing conversation.
\end{abstract}

Keywords Feminism, feminist journal, interdisciplinarity, women's liberation movement, feminist theory and activism.

\section{Resumo}

Uma mesa redonda da Feminist Review sobre as (in)certezas dos rumos seguidos pela revista e pelo seu colectivo

O texto deste artigo resultou dos debates de três mesas redondas que se realizaram ao longo de vários meses entre os diferentes membros do colectivo editorial. Estes debates incidiram sobre momentos intelectuais críticos significativos na vida da revista, bem como sobre algumas continuidades e mudanças na dinâmica e opiniões políticas do próprio Colectivo Editorial. Assim, esta mesa redonda foi escolhida para celebrar os vinte e cinco anos da revista, partilhando reflexões sobre as fecundas in/certezas que foram essenciais nos rumos que traçámos e naqueles que poderemos vir a traçar, enquanto revista e enquanto colectivo editorial, conjuntamente com as nossas leitoras e leitores. Nestas conversas estão presentes o lugar da academia, da política e do feminismo global, assim como as nossas pertenças afectivas e laborais.

Palavras-chave Feminismo, revista feminista, interdisciplinaridade, movimento de libertação das mulheres, teoria feminista e activismo.

\section{Resumen}

Una mesa redonda de la Feminist Review sobre las (in)certitudes de los rumos trazados por la revista y por su colectivo editorial

El texto de este el artículo se fue construyendo a partir de las conversaciones de tres mesas redondas que se han realizado a lo largo de varios meses entre distintos miembros del colectivo editorial. Estos debates han incidido sobre momentos intelectuales significativos de la vida de la revista y, también, sobre algunas de las continuidades y de las 
mudanzas que se han operado en la dinámica y en las opiniones políticas del propio colectivo editorial. Así, se ha escogido estas conversaciones para celebrar los veinte y cinco años de la revista, compartiendo reflexiones sobre las fecundas (in)certitudes que han sido esenciales para los rumos que hemos trazado y para los que podremos trazar en el futuro. En estas conversaciones están presentes el lugar de la academia, de la política y del feminismo global, así como nuestros entornos afectivos y laborales.

Palabras-clave Feminismo, revista feminista, interdisciplinaridad, movimiento de liberación de las mujeres, teoría feminista y activismo.

\section{Introduction}

[For a Full Version of this discussion see Issue 80 of Feminist Review (2005) which celebrated and reflected on 25 years of existence]

The following text has been generated from three roundtable discussions which took place over a series of months between several members from the editorial Collective. ${ }^{1}$ These conversations reflected on significant intellectual turning points in the journal as well as shifts and continuities in the dynamics and politics of the Collective itself. The articles we selected for our 25 years anniversary publication (Issue 80) were chosen through a discussion about the publications - in Feminist Review - that have been hugely influential to the intellectual development of individual autobiographies as well as the social trajectory of feminism(s), in a wider sense. Within these exchanges while the younger generation expressed a desire to hear the histories of the journal, the older members told the past with an anxiety about the inevitable distortion of any one person trying to tell, speak for and represent a variegated set of changes and people across different Collectives. Clearly this is one of many possible narratives of this history. We are particularly aware that the early history of the collective is not fully explored here. This was because only one member of the present collective, Dot Griffiths, was in the collective during this period. The absence of early collective members, and Dot's own reticence about speaking for them has inevitably limited this narrative. Historical fragments are offered in the spirit of trying, however inadequately, to link stories and events over the years which have delivered the present Collective the task of celebrating a quarter of a century of feminist endeavour. So, in this roundtable we have chosen to celebrate 25 years of existence, by sharing reflections on the productive un/certainties that have been critical to the routes we have taken as well those we may take, both as a journal and as a Collective, with

1 The members who participated in one or all of the three round tables that took place between November 2004 to March 2005 in London were the following: AB - Avtar Brah; AT - Amal Treacher; CH - Clare Hemmings; DG - Dot Griffiths; HC - Helen Crowley; IG - Irene Gedalof; JA - Jacqueline Andall; LB - Lucy Bland; LT - Lyn Thomas; NP - Nirmal Puwar. 
our readers. The place of academia, politics, global feminism as well as our own affective bonds and labour form a part of this ongoing conversation.

\section{Part I: hearing and telling}

JA: I think it is important for people on the Collective to hear of developments in the journal - that people have left and people have come back...

$\mathrm{CH}$ : An actual block on the history of the Collective from someone who has been in it for a long period would be good to hear for those of us who have not been in it for that long.

HC: I agree with Dot about the impossibility of any one person representing a collective history. I didn't join the Collective until 1986 but I think there are a few things we can say briefly about the history of the Collective. Shall I have a go?

LT/CH/JA/IG/NP [together]: Yes, Yes.

HC: My encounter with the Collective was when I was in my third year of University at Essex. Mary McIntosh was teaching there, as was Maxine Molyneux and they were two of the founding members. People had been thinking about setting up a feminist journal and then several publishers made approaches, I think, to Elizabeth Wilson. The publisher's overtures were rejected and it was decided to publish Feminist Review independently. The first issue came out in 1979 and the Collective supported itself through subscriptions and fundraising there were 600 subscribers by issue 2 and an individual subscription cost $£ 3.50$. Readers' Groups were an important feature of the journal and meetings of readers were held in different parts of the country. From the outset the journal was very much part of the Women's Liberation Movement (which actually had an office in Covent Garden!). The fundraising events were lots of fun. I remember one in particular, where people made their own badges and one of Elizabeth Wilson's famous hand knitted cardigans - which were magnificent - was auctioned. That particular event was in the town hall in Essex Road from memory and very much part of the political culture of the day - lots of meetings and fundraising activities, and politically the Women's Movement was very exciting.

From the outside the Collective appeared to be a broad church with all the tensions and conflicts of socialist feminism and feminism more generally. There was the influence of Althusserian Marxism, the preoccupations with debates within the Communist Party, the sociology of literature and cultural theory arising out of the Centre for Cultural Studies and of course the central debates of feminism and the feminist critiques mobilized within and against all those different influences. Some of these tensions emerged in the domestic labour debate, which 
deeply preoccupied many people. It was one part of the broad theoretical framework (in FR at least) for the rather stark confrontation between «black» women and white women. I think this was FR's first key role in providing a platform for debate and managing, in spite of all the tensions, to sort of «hold» the debate.

It is hard to convey now the energy and enthusiasms of the Women's Liberation Movement and the intellectual energy of feminist thinking. The journal was important both for the positions the Collective represented but also as a platform for debate. Debates and discussions were passionate and individual women were closely identified with their theoretical positions and arguments. I think a lot of women carried, personally, a great deal of the difficulties of those early debates.

When I joined the Collective in ' 86 it was a large group and I have to say fairly intimidating. Membership had changed quite a lot with only one or two original people still involved. Although FR had been so important in providing a platform for key moments in feminist thinking, particularly around the issue of «race» the Collective was white and predominantly middle class. So the politics of seventies sisterhood masked class as effectively as it masked «race».

$\mathrm{CH}$ : Avtar when did you join? What were the conflicts you came in on? Tell us the story.

AB: Well what happened was that my involvement started with Chandra's article because I was asked to give an external assessment of it. I mean I thought it was a brilliant piece, which it is. Kum-Kum Bhavnani had already joined the Collective at that point, because I refereed it she then got me involved. Then we got Gail involved as well. For us actually, partly we were outnumbered. There were only two, three of us in what was a very large Collective. At an inter-personal level one can say a lot of things but I don't think that's necessarily that important.

What we began to realise however was that women weren't aware of their whiteness, that language was not there at the time. But the fact that there were white women, the whole question of racialisation - there wasn't any general awareness of it and the content of Feminist Review did not reflect those differences either. So what we tried to do was to try and say that the Collective should try to address these issues in terms of the content of the journal but at the same time as far as possible try to have women of colour. Equivalent numbers if possible but at least as many as possible. But it wasn't just a question of numbers there was also a racialised form of intellectual elitism. It was almost as if somehow «we» the «black» women, were not really of the same level. It was never said, of course.

HC: Like the working class women.

AB: Yes. It was never said - who would, my god. But the feeling we would get would be like that. The «black» women were not the ones who were seen to 
be the theorists. I was very badly affected by an incident that pointed to this. Gail was there, Kum-Kum was there, and we all noticed it. Again I won't personalise it. We didn't even have to explain, we looked at each other and we knew. We began to think this is not simply a case of having a few more «black» women in. It is really very much a question for all of us, of what today we call our subjectivity. How were we being constituted on the Collective itself as «black» women as well as white women?

A little bit later we went to our annual gathering at Bore Place in the big house.

HC: The weekend away.

$\mathrm{AB}$ : We were discussing all these questions; we were raising these issues at the weekend away. And actually the way the whole thing developed it became quite direct. Some of us, I think it was Gail and I, we actually sort of sensed, I don't remember what it was, but it was quite direct. We didn't mince words.

HC: It was the use of «we», the inclusive we.

$\mathrm{AB}$ : That was when the tension really came out into the open wasn't it?

NP: What year was this?

AB: This would be, was it 89 ? I joined in 88.

NP: A few years after Many Voices...

AB: Quite a few years after Many Voices... We went in to the Collective thinking they have produced that issue, this is really moving forward. We were shocked actually. In reality nothing happened after that issue, in terms of «race» and racism.

AB: After that weekend away we decided that as «black» women we did not want to continue, unless the Collective decided to change. We very directly actually challenged whiteness, I mean we talked about white women and «black» women and the differences. We felt that there was no point in us staying inside unless everyone was willing to own the issue itself and to discuss it.

$\mathrm{HC}$ : And it was something people found very difficult, that people were not willing to do.

AB: Which is something you'd have to tell us because we left. We said we'd consider perhaps coming back... 


\section{JA: So you left?}

$\mathrm{AB}$ : That was quite a difficult phase for the Collective. We were gone for a year, was it? That is something that you would obviously know.

HC: Yes well it was a very difficult phase because of that but also because all the certainties were going. All of the certainties out of which the journal had come, which was socialist feminism, all of those certainties had become deeply problematic. Questions of class, socialism, feminist theory and feminism itself were all loosing their anchors. The fracturing was very troubling.

AB: A lot of women left at that point, it was very significant the number that left at that point.

\section{$[\ldots]$}

HC: It was smaller but it was something else as well. The certainties had gone.

Many of us felt dispossessed particularly of our roots in Marxism which had been such a powerful part of our intellectual life. That debate between Marxism and feminism, was very powerful and lots of people felt terribly adrift at the failures of Marxism as a theoretical force, even though feminism had been instrumental in its undoing. So the Collective was a lot smaller but it didn't any longer have the original mission that it had. Both because of the challenge of «black» feminists but also because of the wider landscape and shifts that had happened.

NP: What do you feel that you lost the Marxism to? Do you mean the newly formed cultural studies? I mean because some people carried on the Marxism in a different way in cultural studies, didn't they? A lot of cultural studies is still quite Marxist but in a different way.

HC: Well everything is still quite Marxist but nobody was in/within Marxism in the same way. So what year are we up to now?

AB: Post 89 , so we are talking about the nineties now really.

JA: I found it interesting when you said that when the journal started they had some editorial autonomy, what happened to that? When did you switch to a corporate publisher and what brought about that change?

HC: Hmm. I think some people thought self publishing was slightly cottage industry-ish and that it needed to be professionalised. But moving to a publisher never involved surrendering editorial control. 
$[\ldots]$

HC: It was a Friday night, you know, glass of wine, chopping the food up and feast on the agenda. And during this there was a difficult exchange around an assumed heterosexuality.

\section{$\mathrm{CH}$ : But when was that!?}

HC: 88 . What I mean is the exchange illustrated (for me anyhow) that, even though there was a great deal of debate on sexuality, many of us still assumed a heterosexual world much as we assumed a white world. I often think back on that evening and how hard it was, really, to grasp the question of difference.

$\mathrm{CH}$ : Yes, yes. I think what is interesting - I mean in some ways this is a similar sort of question as Nirmal's - that there were other places where these debates were happening. (So I am thinking that is quite late for a debate about sexuality.)

LB: In terms of where sexuality was in the journal, I can remember this incredibly important article - «Upsetting an Applecart» - and that led to great debates, reflecting those splits around sexuality. And there were one or two others and then there were debates on pornography. Actually I think FR was a place where there were important debates going on about sexuality which certainly had wider ripple effects.

AB: Absolutely. But if you looked at the composition of the Collective itself there were very few women. If you are a mixed group - where there are lesbian women, heterosexual women - sometimes issues get centred because it is also a part of your life. You are right that was a very important issue. But if you actually look at all the articles we had published there was less of a presence of sexuality.

LB: Dot, you have been on the Collective from the beginning. So what is your sense of the significant changes in the Collective?

DG: Yes, that's very hard, because in a way I was very engaged with feminism but now I don't feel engaged at almost any level. I can ask questions now but I can't give answers. And I suppose I can say we don't have a clear sense of what we are now. And I suppose we had a clearer sense of what we were, rightly or wrongly, when we started in 1979 or whenever we started. I have been around a long time but I don't want only two voices to carry too much of history really.

NP: For us it was important to hear the history, it gave some real life to conflicts and tensions that are often just displayed in theoretical terms. I think it was 
very important memory work. It will just stay with me as it was almost like a film they unfolded for us from behind the scenes.

$\mathrm{CH}$ : It was actually very moving. There was a real feeling of the relationship of the struggles among the Collective and hearing about the struggles that were taking place at a theoretical and historical level is interesting; I want to hear more of it.

NP: So do I.

\section{Part II: turning point articles}

Having heard some of the historical accounts, we turned to discussing the articles we should publish in our anniversary issue on the basis that they represent significant turning points for us?

[Due to word limit we have not been able to publish this discussion here. Please see Feminist Review Issue 80 for a full version of the text]

\section{Part III: surviving as a collective}

The rich array of publications we have been able to select from have relied on the very survival of the journal and the Collective which itself can not be taken for granted.

\section{Part IV: interventions today}

So what kinds of interventions do we see ourselves making today and in the future directions of the journal?

$\mathrm{CH}$ : I think there are lots of young women who are politically active. The interesting thing is that they may not be found in academia in the way that we were. Maybe one needs to look in different places.

NP: Well I don't think there is a lack of them, I definitely don't. I actually think there is quite a lot, there are loads coming through, more than my own generation. There is a difference though; they occupy quite a different space. They are quite creative - multimedia, film, web technologies. They do the theory but they are quite creative as well. They produce things; they don't necessarily want to be academics. 
IG: I think it is related to the question of what we mean by politics and what we mean by feminist politics and how that relates to the journal as an academic journal but as a space for feminist politics as well. One way these sorts of considerations can impact on us is that we don't foreclose too quickly on what we mean by the political. Yes it means absolutely what Nirmal is talking about, defining new spaces that in earlier moments might not have been seen as truly political, purely political or political enough - the political from below. But it also means thinking about that very messy space up above - of if you like, femocrats - which may not be where we ourselves want to be but is worth paying attention to and worth reflecting on and encouraging serious critical academic reflection. There are important questions about the mainstreaming of feminism and the impact of this that need exploring. I think that one of our jobs with the journal should be to think about what we see as the new, big questions facing feminism today, and to carry on re-creating a space where these can be debated seriously.

NP: We are quite privileged aren't we? It's about how you see your job. I think we have a responsibility to do it, that's the way I see it. In my bag here I have a book by Edward Said, Humanism and Democratic Criticism, his last lectures. He talks about how as an intellectual you should be a critic, and not just a writing critic.

LT: That's also very French. French intellectuals do political intervention all the time, Pierre Bourdieu for example. It's not very British.

IG: But we are in this space. This is where I feel this contradiction. The space of Feminist Review. To me writing is a political intervention, the sense of thinking through the issues. Yet none of us bring our current work to the Collective, to get feedback on, to think through issues. And I feel that is a bit bizarre, to be honest.

AT: There is that whole question that Nirmal has been gnawing away at about a bit this afternoon about academia and the political and how we situate ourselves within that, or not.

JA: So again it is about politics and activism.

HC: It can't survive without the connection between it as an academic journal and as activism.

AT: Well there are loads of pure academic feminist journals that do survive. It depends on how you want to force it. It takes us to a set of questions - what is it about the journal Feminist Review that we want to hang on to, what do we want to strengthen? In other words what kind of journal do we want to be engaged in? What is relationship to our local feminisms, activisms and what is our relationship to international feminism? 
Nirmal Puwar is Senior Lecturer in the Department of Sociology, Goldsmiths, University of London, and is a member of the Feminist Review editorial Collective since 2000.

http://ww.feminist-review.com.

E-mail: n.puwar@gold.ac.uk

Artigo recebido em 10 de Março de 2009 e aceite para publicação em 15 de Abril de 2009. 